Persp. Teol. 39 (2007) 21-47

\title{
MINISTÉRIOS E SERVIÇOS LITÚRGICOS \\ NUMA IGREJA TODA MINISTERIAL \\ A MINISTERIALIDADE EM DOCUMENTOS \\ DO MAGISTÉRIO PÓS-CONCILIAR (II)*
}

José Raimundo de Melo SJ

\section{Os demais serviços na assembléia litúrgica}

\section{a) Leitores}

\begin{abstract}
função ministerial do leitor é antiga, venerável e importantíssima no

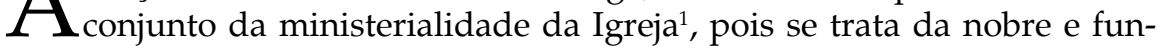
damental missão confiada a alguns de proclamar aos irmãos, reunidos em assembléia litúrgica, a santa Palavra de Deus. Através da voz daquele que lê as Sagradas Escrituras na celebração, Deus fala ao seu povo, e por meio da sua expressão vocal, o povo pode receber inteligivelmente a mensagem salvífica de seu Senhor. Tudo isto nos mostra, pois, como este serviço é central na liturgia cristã, justificando a atenção e o cuidado com que a Igreja deseja vê-lo realizado.
\end{abstract}

\footnotetext{
* A primeira parte deste artigo foi publicada em Persp. Teol. 38 (2006) 349-374. 1 "A figura do leitor liga-se aos inícios do culto cristão, antes, deita as suas raízes no culto sinagogal hebraico. Jesus mesmo realizou esta tarefa na sinagoga de Nazaré (Lc 4,16)" (I. SCICOLONE, "Il canto dei ministri nella liturgia", Bollettino Ciciliano. Rivista di musica sacra 78 (1983) 23-29, aqui p. 27).
} 
Tratando-se de leitores, duas observações se impõem como principais. Em primeiro lugar, nem todos podem executar esta tarefa na Igreja, mas somente aqueles que preenchem os requisitos básicos necessários ao ministério, sejam eles de tipo técnico ou espiritual. E a estes requisitos os documentos se fazem bem sensíveis. Por outro lado, podemos distinguir dois tipos de leitores: os que assumem esta função através de um rito litúrgico de instituição, e são comumente chamados de "leitores instituídos", e os, digamos, "temporários ou fortuitos", que realizam tal serviço atendendo a uma necessidade imediata da comunidade, mas sem terem sido instituídos ou manterem um vínculo fixo com o ministério. Além do mais, temos aqueles que são instituídos liturgicamente no leitorado, mas apenas como um degrau em direção às ordens sacras.

Com a Carta Apostólica Ministeria quaedam², pela qual foi abolida a ordem do subdiaconato na Igreja latina, as atividades antes desenvolvidas pelo subdiácono retornaram ao leitor e ao acólito, mesmo estes não tendo sido instituídos 3 .

Nos vários textos sobre o leitorado encontramos basicamente duas afirmações: uma que tende mais a descrever a função desses ministros e outra que alerta para o respeito e o cuidado com que ela deve ser realizada no culto litúrgico. Analisemos brevemente estas duas afirmações.

\section{- A função do leitor}

O n. 13 da Instrução Musicam Sacram ${ }^{4}$ reconhece a precisa importância do leitor quando diz que na assembléia ele ocupa um peculiar lugar pelo ofício que aí exerce ${ }^{5}$. A Instrução Geral sobre o Missal Romano ${ }^{6}$, descrevendo os ministérios particulares, em vista de uma mais intensa participa-

2 PAULUS VI, Litterae Apostolicae Motu proprio datae Ministeria quaedam, 15 de agosto de 1972 (nova disciplina sobre a primeira tonsura, ordens menores e subdiaconato na Igreja latina), AAS 64 (1972) 529-534.

${ }^{3}$ As funções do subdiácono serão realizadas pelo leitor ou acólito, mesmo se não são juridicamente instituídos (cf. SAGRADA CONGREGAÇÃO DO CULTO DIVINO, Variações Cum die 1 ianuarii, de 23 de dezembro de 1972 (alterações introduzidas no Missal Romano após a abolição da ordem do subdiaconato na Igreja latina), Notitiae 9 (1973) 3438).

${ }^{4}$ SAGRADA CONGREGAÇÃO DOS RITOS, Instrução Musicam sacram, de 5 de março de 1967 (sobre a música na sagrada liturgia), AAS 59 (1967) 300-320; Notitiae 3 (1967) 87-105; a seguir citada pelas iniciais MS.

5 "Nessa ocupam um lugar particular, pela sagrada ordem recebida, o sacerdote e os seus ministros; e pelo ofício que realizam, os ministrantes, os leitores, ..." [MS 13].

${ }^{6}$ CONGREGAÇÃO PARA O CULTO DIVINO E DISCIPLINA DOS SACRAMENTOS, Instrução Geral sobre o Missal Romano, in $3^{\text {a }}$ Edição Típica do Missal Romano, 2002 (edição para o Brasil aprovada pela Congregação em carta de 30 de julho de 2004). Tal Instrução será citada aqui em sua nova numeração, como aparece reformulada na $3^{\text {a }}$ edição Típica do Missal. A seguir, citada pelas iniciais IGMR. 
ção de todos na celebração, diz: "O leitor é instituído para proferir as leituras da Sagrada Escritura, exceto o Evangelho. Pode igualmente propor as intenções para a oração dos fiéis e, faltando o salmista, recitar o salmo entre as leituras". E, concluindo, oportunamente declara: "Na celebração eucarística, o leitor tem uma função própria" (n. 99). Mas o texto não se interessa apenas pelo leitor instituído, como observa a seguir:

Na falta de leitor instituído, sejam delegados outros leigos, realmente capazes de exercerem esta função e cuidadosamente preparados para proferir as leituras da Sagrada Escritura, para que os fiéis, ao ouvirem as leituras divinas, concebam no coração um suave e vivo afeto pela Sagrada Escritura (n. 101).

Este afeto vivo e suave pela Escritura, expressão tirada da SC 24, indica o grau de atenção da Igreja pela função do leitor. Em seguida se sugere que "havendo várias leituras, é bom que sejam distribuídas entre diversos leitores ..." (n. 109; cf. Redemptionis Sacramentum 437). Outro artigo da mesma IGMR, descrevendo a ordem em que os ministros se dirigem ao altar para a missa, elenca também o leitor, "... que pode conduzir um pouco elevado o Evangeliário" [n. 120d].

Os artigos 194-198 da IGMR apresentam as funções do leitor na celebração da missa. O n. 194 dá as mesmas prescrições quanto à condução do livro dos Evangelhos que encontramos no artigo 120d. No n. 195, chegando com os outros ministros ao altar e fazendo-lhe a devida reverência, "se levar o Evangeliário, sobe ao altar e depõe o Evangeliário sobre ele. A seguir, ocupa, com os demais ministros, seu lugar no presbitério". Na parte da liturgia da Palavra, "profere, do ambão, as leituras que precedem o Evangelho". Na falta do salmista, "... pode proferir também o salmo responsorial depois da primeira leitura" [n. 196]. E ausente o diácono, "... pode proferir, do ambão, as intenções da oração universal" [n. 197]. No n. 198, enfim, "se não houver canto à Entrada e à Comunhão, e os fiéis não recitarem as antífonas propostas no missal, o leitor as pode proferir no momento oportuno".

O leitor assume assim uma função específica na assembléia quanto ao anúncio da Palavra, mas também uma função substitutiva, no caso de faltarem outros ministros. Esta função própria se fundamenta na tradição mesma da Igreja, como nos diz o artigo 49 do Elenco das Leituras da $M i s s a^{8}$ : "A tradição litúrgica confiou a função de proclamar as leituras

${ }^{7}$ CONGREGAÇÃO PARA O CULTO DIVINO E DISCIPLINA DOS SACRAMENTOS, Instrução Redemptionis Sacramentum, de 25 de março de 2004 (sobre alguns aspectos que se devem observar e evitar acerca da SSma. Eucaristia), São Paulo: Paulinas, 2004 (= Documentos da Igreja 16).

${ }^{8}$ Missal Romano, restaurado por Decreto do Concílio Ecumênico Vaticano II e promulgado pela autoridade do Papa Paulo VI, Ordo Lectionum Missae, Praenotanda, $2^{\mathrm{a}}$ ed. de 1981, Notitiae 17 (1981) 358-462 (edição para o Brasil: Elenco das Leituras da Missa, Introdução, in: Lecionário Dominical, anos $A, B e C$ ), a seguir citada pelas iniciais OLM. 
bíblicas ... a ... leitores e diácono". A seguir este mesmo documento, após recordar como a IGMR 99 que o leitor exerce um ofício que lhe é próprio, mesmo achando-se presentes ministros de ordem superior, continua a afirmar na linha da Ministeria quaedam 5:

Estando presentes leitores instituídos, realizem a sua função pelo menos no domingo e nas festas, especialmente durante as celebrações principais. Além disso, pode-se confiar a eles o encargo de ajudar na organização da liturgia da Palavra e cuidar, se for necessário, da preparação de outros fiéis que, por designação temporária, devem fazer as leituras na celebração da missa [OLM 51].

Esta última observação é digna de nota. Além da função normal de proferir as leituras na assembléia, o leitor é ainda convidado a preparar outros leitores para o cargo temporário da proclamação das leituras. Isso faz dele, mais do que um simples executor material da função, um verdadeiro responsável pela proclamação das leituras na assembléia eucarística.

Um grupo de textos insiste ainda em esclarecer que o leitor deve proclamar somente as leituras que antecedem o evangelho, sem jamais ler o evangelho. Segundo estes textos, o anúncio do evangelho na celebração da eucaristia é reservado aos ministros ordenados, como se pode constatar nas passagens: IGMR 59, 99, 196; OLM 49, 50; Inaestimabile donum $2^{9}$. Na Instrução Actio Pastoralis ${ }^{10}$, além de se demonstrar uma tal exigência, se esclarece que: "As leituras que precedem o Evangelho poderão ser lidas por qualquer participante (homem ou mulher) ..." [n. 6f]. Enquanto que o leitorado instituído é conferido somente a homens, a faculdade de ler na missa os textos das Sagradas Escrituras que antecedem o evangelho é concedido a fiéis de ambos os sexos.

\section{- O modo a ser exercido o leitorado na assembléia}

Também são oferecidas orientações quanto ao modo de o leitor executar a sua função na assembléia eucarística e o profundo zelo que ela exige daqueles que se dispõem a desempenhá-la. A MS 26 ordena a todos os que usam a voz nas celebrações a que "... profiram as partes a eles assinaladas de modo bem inteligível, a fim de tornar mais fácil e quase natural a resposta dos fiéis, quando exigida pelo rito". Recomendação semelhante se encontrará também na Instrução Eucharisticum Mysteriumm ${ }^{11}$, n. 20.

${ }^{9}$ SAGRADA CONGREGAÇÃO DOS SACRAMENTOS E DO CULTO DIVINO, Instrução Inaestimabile donum, de 3 de abril de 1980 (sobre algumas normas relativas ao culto divino), AAS 72 (1980) 331-343.

${ }^{10}$ SAGRADA CONGREGAÇÃO DO CULTO DIVINO, Instrução Actio pastoralis, de 15 de maio de 1969 (sobre a missa para grupos particulares), AAS 61 (1969) 806-811; Notitiae 6 (1970) 50-55.

${ }^{11}$ SAGRADA CONGREGAÇÃO DOS RITOS, Instrução Eucharisticum Mysterium, de 25 de maio de 1967 (sobre o culto do mistério eucarístico), AAS 59 (1967) 539-573. 
O Diretório para missas com crianças ${ }^{12}$ também se interessa muito pela proclamação das leituras nestas assembléias: "para as leituras, por ex., e para os cantos se recorra tanto às crianças como aos adultos. Graças à variedade das vozes, se evitará a monotonia" [n. 24]. E chama ainda a atenção para a maneira própria como os textos são pronunciados aí: "Por outro lado, deve-se estar atento - e com maior diligência do que nas missas para os adultos - que os textos litúrgicos sejam pronunciados de forma inteligível, sem pressa e com as devidas pausas" [n. 37]. Tal sensibilidade da Igreja hoje pela compreensão das crianças é muito útil, pois a vivência religiosa futura destes pequenos cristãos muito dependerá da maneira como receberam a mensagem durante o período de infância.

Dominicae cenae n. $10^{13}$ recorda que a partir da renovação introduzida pela reforma pós-conciliar, "nascem grupos de leitores e de cantores ... que com grande zelo dedicam-se a tal aspecto". E um pouco além, conclui afirmando:

Portanto, estas exigências que brotam da nossa responsabilidade frente à Palavra de Deus na liturgia, chegam ainda mais no profundo e tocam a disposição interior com a qual os ministros da Palavra realizam a sua função na assembléia litúrgica [n. 10].

A reforma litúrgica proporcionou uma maior aproximação entre o povo e liturgia, e também aumentou as exigências em relação àqueles que no meio da assembléia devem realizar o serviço da Palavra.

Já o OLM de maneira positiva e profunda vai dizer que "a assembléia litúrgica precisa ter leitores, ainda que não tenham sido instituídos para esta específica função. Para isso é preciso prever que haja à disposição alguns leigos particularmente idôneos e preparados para realizar este ministério" [OLM 52]. E o n. 54 exige do sacerdote, do diácono e do leitor instituído a utilização da veste sagrada própria do seu ofício, mas não no caso dos leitores não instituídos, que podem usar a veste comum, salvo, porém, os costumes próprios das várias regiões ${ }^{14}$. O máximo da afirmação

\footnotetext{
${ }^{12}$ SACRA CONGREGAÇÃO DO CULTO DIVINO, Directorium de Missis cum pueris ("Pueros baptizatos"), de $1^{\circ}$ de novembro de 1974 (Diretório para missas com crianças, publicado no Brasil na $2^{a}$ parte dos Documentos da CNBB, $n^{\circ} 11$ ), AAS 66 (1974) 3046.

${ }^{13}$ JOÃO PAULO II, Dominicae Cenae: Carta aos bispos da Igreja universal, de 24 de fevereiro de 1980 (sobre o mistério e o culto da ss. eucaristia), AAS 72 (1980) 113-148; Notitiae 16 (1980) 125-154.

14 "O sacerdote, o diácono e o leitor instituído, quando sobem ao ambão para proclamar a Palavra de Deus na celebração da Missa com o povo, devem usar as vestimentas sagradas próprias de seu ofício. Todavia, os leitores não instituídos que em alguns casos ou mesmo habitualmente desempenham o ministério de leitor, podem subir ao ambão com sua roupa normal, respeitando-se porém os costumes das diversas regiões" [OLM $54]$.
} 
sobre o leitor na Introdução do Elenco das Leituras da Missa, nós encontramos, porém, num artigo seguinte, que abaixo transcrevemos:

Para que os fiéis, ao ouvirem as leituras divinas, concebam no coração um suave e vivo afeto pelas Sagradas Escrituras, é necessário que os leitores, mesmo que não tenham sido instituídos para essa função, sejam realmente capazes de desempenhá-la e se preparem cuidadosamente. Esta preparação deve ser sobretudo espiritual; mas é também necessária a preparação propriamente técnica. A preparação espiritual supõe, pelo menos, uma dupla formação: bíblica e litúrgica. A formação bíblica deve levar os leitores a saber compreender as leituras no seu contexto próprio e entender à luz da fé o núcleo central da mensagem revelada. A formação litúrgica deve facilitar aos leitores certa percepção do sentido e da estrutura da Liturgia da Palavra e as motivações da relação entre a Liturgia da Palavra e a Liturgia eucarística. A preparação técnica deve capacitar os leitores para que se tornem sempre mais aptos na arte de ler diante do povo, seja de viva voz, seja com a ajuda dos modernos instrumentos para a amplificação vocal [OLM 55].

De início o texto apresenta uma citação da IGMR 99, conforme a nota 93 da OLM. Mas a IGMR nesta parte praticamente apresenta uma transcrição da SC 24, como já vimos acima. Assim, toda a preparação do leitor tem por finalidade criar nos fiéis um intenso e vivo afeto pela Palavra de Deus que na celebração é anunciada. E tal preparação não é só missão dos leitores instituídos, mas de todos os que proclamam a mensagem bíblica no culto da assembléia. É relevante ainda a continuação do texto, que se põe a descrever a formação necessária ao leitor. Não se trata apenas de uma preparação periférica, exterior, mas também e sobretudo interior, profunda. Ela deve ser "... uma preparação espiritual e técnica ...", conforme já havia lembrado a Inaestimabile donum 2.

Quando os livros litúrgicos enunciam a ação própria do leitor na celebração, por vezes utilizam expressões como: proclamar, proferir, anunciar, cantar ... Convém observar que o sentido do proclamar é: "declarar publicamente em voz alta e com solenidade; anunciar; declarar enfaticamente; afirmar, asseverar; decretar, publicar". Isso já nos mostra a responsabilidade daquele que proclama os textos sagrados na Igreja. Sua atitude não deve ser apenas "ler" o texto, mas comunicação segundo o espírito da mensagem que a boca anuncia. Daí a necessidade de uma preparação tanto técnica como espiritual.

Já o missal e o ritual dos sacramentos, quando se referem às orações presidenciais, preces e salmos responsoriais, usam os verbos "dizer", "recitar" e "cantar", enfatizando a atitude contemplativa, orante, meditativa da Igreja que, nestes momentos, se une de modo todo particular ao seu Senhor.

A Palavra de Deus que é tanto "viva", quanto "eficaz" (cf. Hb 4,12), recebe força nova quando na assembléia é liturgicamente anunciada. $\mathrm{O}$ leitor ou o diácono dando, por meio do seu ministério, voz ao texto escrito, torna- 
se verdadeiro profeta, apóstolo e evangelista. A sua proclamação deveria, de um lado, re-propor a voz do hagiógrafo e, de outro, exprimir a fé segura de que o autor principal do texto é efetivamente o Espírito Santo ${ }^{15}$.

\section{b) Acólitos}

Aqui também, como no caso do leitor, distinguem-se os acólitos instituídos através de um rito litúrgico, e os acólitos ocasionais ou fortuitos. Estes últimos realizam o serviço de acólitos, mas sem manter um vínculo fixo com este ministério, o que, ao contrário, sucede com os ministros instituídos. E identicamente ao que sucedia com o leitorado, temos ainda aqueles que se fazem acólitos como um degrau em direção às sagradas ordens.

O acólito executa na liturgia um ofício de significativo valor. Esta função, porém, é descrita quase que exclusivamente no texto da IGMR. Com efeito, na parte do documento que elenca os ministérios particulares exercidos na assembléia, encontramos a seguinte caracterização do serviço do acólito:

O acólito é instituído para o serviço do altar e para auxiliar o sacerdote e o diácono. Compete-lhe principalmente preparar o altar e os vasos sagrados, e, se necessário, distribuir aos fiéis a Eucaristia, da qual é ministro extraordinário [IGMR 98].

Este texto apresenta como que uma síntese da função do acólito instituído: o serviço da mesa do Senhor, incluindo a sua preparação prévia, e o auxílio ao sacerdote na distribuição do pão eucarístico aos fiéis. O acólito instituído, na verdade, recebe automaticamente o ministério extraordinário da comunhão eucarística por ocasião do rito de instituição. A Igreja recorda, porém, que este ministério da comunhão dos acólitos é de caráter suplementar e deve ser realizado somente como auxílio aos sacerdotes e diáconos, ministros estes ordinários da eucaristia [cf. também Dominicae cenae 11].

A IGMR 116 vai dizer que a celebração de qualquer missa comporta normalmente a presença do acólito ${ }^{16}$. Já os nn. 187-193 descrevem os ofícios do acólito. De fato, "as funções que o acólito pode exercer são de diversos tipos ..."; por isso convém que sejam distribuídos entre várias pessoas [n. 187]. Na procissão inicial, "o acólito pode levar a cruz ... depõe a cruz perto do altar. Em seguida, ocupa o seu lugar no presbitério" [n. 188]. E ao longo da celebração, “... cabe ao acólito aproximar-se do sacerdote ou do diácono, para lhes apresentar o livro e ajudá-los em outras coisas necessárias" [n. 189]. Na falta do diácono, prepara o altar para a apresentação dos dons e ajuda o sacerdote a receber as oferendas. E havendo incenso, apresenta ao

${ }^{15}$ Cf. I. SCICOLONE, "Il canto dei ministri nella liturgia", art. cit., p. 27.

16 "Convém, entretanto, que o sacerdote celebrante seja assistido normalmente por um acólito, um leitor e um cantor. $\mathrm{O}$ rito descrito em seguida prevê, porém, a possibilidade de maior número de ministros" [IGMR 116]. 
sacerdote o turíbulo e o assiste na incensação ${ }^{17}$. Pode ainda auxiliar o sacerdote na distribuição da comunhão, mas somente se foi instituído como ministro extraordinário da mesma ${ }^{18}$. O acólito legalmente instituído "... ajuda o sacerdote ou o diácono a purificar e arrumar os vasos sagrados ..." e, ausente o diácono, "... leva os vasos sagrados para a credência e ali, como de costume, os purifica, os enxuga e os arruma" [n. 192].

\section{c) Salmistas}

O ministério do salmista, encarregado do canto ou proclamação dos salmos na assembléia eucarística, recebeu ao longo da tradição cristã significativa importância. O canto dos salmos na liturgia, conforme assinala J.A. Jungmann, é usado desde a Igreja antiga, e tal costume foi se desenvolvendo cada vez mais através dos séculos ${ }^{19}$. O encarregado da proclamação dos salmos na tradição romana, porém, não era ordenado para tal e nem era instituído nesta função; o ministério do salmista jamais foi contado entre as ordens sacras da Igreja ${ }^{20}$. Tratava-se de um cargo que podia ser conferido pelo simples sacerdote, mesmo sem o concurso do bispo ${ }^{21}$.

Segundo o Ordo Romanus I, antes do início da missa deveria ser comunicado ao papa tanto o nome do leitor da Epístola, como o do cantor do salmo ${ }^{22}$. J.A. Jungmann assinala ainda que antes da época do papa Gregório Magno, o canto dos salmos era confiado a diáconos, o que veio a ser proibido pelo próprio Gregório, no Sínodo romano de 59523, com a finali-

\footnotetext{
17 "Não havendo diácono, depois de concluída a oração universal, enquanto o sacerdote permanece junto à cadeira, o acólito põe sobre o altar o corporal, o purificatório, o cálice, a pala e o missal. A seguir, se for o caso, ajuda o sacerdote a receber os donativos do povo e, oportunamente, leva para o altar o pão e o vinho e os entrega ao sacerdote. Usandose incenso, apresenta ao sacerdote o turíbulo e o auxilia na incensação das oferendas, da cruz e do altar. Em seguida, incensa o sacerdote e o povo" [IGMR 190].

${ }^{18}$ Cf. PAULUS VI, Ministeria quaedam 6: AAS 64 (1972) 532; IGMR 191.

${ }^{19}$ Cf. J.A. JUNGMANN, Missarum sollemnia. Origini, liturgia, storia e teologia della messa romana, vol. I, Torino: Marietti, $1961^{2}$, p. 341.

${ }^{20}$ Cf. I. SCICOLONE, "Il canto dei ministri nella liturgia", art. cit., p. 29.

${ }^{21}$ O Sacramentário Gelasiano, retomando os Statuta Ecclesiae antiquae, assim se expressa sobre a função do salmista: "O salmista, isto é, o cantor, pode sem o conhecimento do bispo e só com a ordem do presbítero, receber o ofício de cantar, dizendo a ele o presbítero: Vê que aquilo que cantas com a boca, creias com o coração e aquilo que crês com 0 coração, proves através das obras" (Ge 746: Liber sacramentorum romanae ecclesiae ordinis anni circuli. Romae, 1961, 117 [= Rerum Ecclesiasticarum Documenta, Series Maior, Fontes IV]). Esta mesma prescrição aparece ainda no Pontifical Romano-Germânico (cf. Le Pontifical Romano-Germanique du dixième siècle. Le texte I, Cap. XV,8, éd. C. VOGEL, Città del Vaticano: Biblioteca Apostolica Vaticana, 1963, 14-15 [= Studi e testi 226]).

22 "Enquanto o subdiácono regional lê o apóstolo, o da Schola canta" (Talis subdiaconus regionarius legit apostolum et talis de Schola cantat ) [Ordo I,38: Les Ordines Romani du haut Moyen âge, éd. M. ANDRIEU, vol. 2, Louvain, 1960, p. 80 (= Spicilegium Sacrum Lovaniense 23]).

${ }^{23}$ Cf. PL 77,1335, citado por J.A. JUNGMANN, Missarum sollemnia I, 348 e nota 72.
} 
dade de evitar que uma bonita voz pudesse influir na promoção de alguém ao diaconato. Desta forma, a função passa ao subdiácono, e sucessivamente a qualquer grau de ordenação ${ }^{24}$.

O salmista não é um leitor que profere o seu texto, mesmo quando ele deve "ler" o salmo. O salmista não é nem mesmo um cantor, também se na maioria das vezes deva ele "cantar" o salmo. O salmista é essencialmente um "orante", que reza e conduz toda a assembléia a rezar junto com ele por meio do salmo cantado ou lido. Daí a necessidade de uma correta preparação espiritual e técnica, unida a uma grande sensibilidade pessoal, que lhe permita realizar bem este ministério, levando a comunidade a uma intensa experiência de oração. Como podemos bem notar, trata-se de uma missão não fácil, a ser confiada somente a pessoas de profunda oração e grande interiorização. Observemos, a seguir, o que nos dizem os nossos documentos sobre o serviço do salmista na assembléia dos fiéis.

Da função do salmista nos falam a IGMR e a OLM em alguns artigos. No texto da IGMR, o ministério do salmista aparece incluído entre as funções particulares da celebração. A este propósito o documento vai afirmar:

Compete ao salmista proclamar o salmo ou outro cântico bíblico colocado entre as leituras. Para bem exercer a sua função é necessário que o salmista saiba salmodiar e tenha boa pronúncia e dicção [IGMR 102].

O artigo apresenta como critério para ser salmista o saber salmodiar e ter boa pronúncia e dicção. O OLM, claramente inspirado nesta passagem da IGMR, vai também se deter na apreciação destas exigências:

Para exercer esta função de salmista é muito conveniente que em cada comunidade eclesial haja leigos dotados da arte de salmodiar e de uma boa pronúncia e dicção. $\mathrm{O}$ que se disse anteriormente sobre a formação dos leitores também se aplica aos salmistas [OLM 56].

Nestas observações que aqui são feitas ao salmista vem incluído tudo aquilo que acima elencamos como características necessárias àquele que exerce este ministério: preparação espiritual, vida de oração, dom natural, conhecimentos técnicos.

A IGMR 61, tratando dos cantos interlecionais, oferece algumas indicações quanto ao lugar da salmodia na assembléia:

Assim, o salmista ou cantor do salmo, do ambão ou outro lugar adequado, profere os versículos do salmo, enquanto toda a assembléia escuta sentada, geralmente participando pelo refrão, a não ser que o salmo seja proferido de modo contínuo, isto é, sem refrão ... Se o salmo não puder ser cantado, seja recitado do modo mais apto para favorecer a meditação da Palavra de Deus.

${ }^{24}$ Cf. J.A. JUNGMANN, Missarum sollemnia I, 348-349 e nota 73. 
Vemos aqui que o salmo responsorial é proferido "na estante ou outro lugar adequado", mas na IGMR 309 são dadas indicações para que o salmo seja proferido somente do ambão: "Do ambão são proferidas somente as leituras, o salmo responsorial e o precônio pascal; também se podem proferir a homilia e as intenções da oração universal ou oração dos fiéis. A dignidade do ambão exige que a ele suba somente o ministro da Palavra". Idêntica assinalação quanto ao lugar do anúncio dos salmos encontramos no OLM 33: "Dado que o ambão é o lugar de onde os ministros proclamam a Palavra de Deus, deve ser reservado, pela sua natureza, às leituras, ao salmo responsorial e ao precônio pascal". Anteriormente o mesmo OLM já havia determinado que: "O salmo responsorial é cantado ou recitado por um salmista ou por um cantor, estando este no ambão" [OLM 22], levando-nos a crer que o ambão é, na igreja, o lugar único e preciso de onde deve ser feito o salmo responsorial ${ }^{25}$.

Importa ainda observar que, nos territórios em que se usava a liturgia franco-romana, quando o salmista subia ao ambão para o canto dos salmos, não permanecia no alto deste mas, igual ao leitor da epístola, punhase num degrau intermédio, o gradus, derivando daí o nome de "Graduale" a este canto ${ }^{26}$.

\section{d) Cantores, schola cantorum, instrumentistas}

O ministério do cantor, da schola cantorum e dos instrumentistas concorre para uma celebração eucarística mais profunda e mais intensa na assembléia dos fiéis. Todos estes serviços têm uma função precisa no culto da assembléia, nos dirão os textos, o que concorre para superar uma idéia segundo a qual o canto e a música são meros contornos da celebração, cuja função é só decorativa, mas que não entram na ação celebrativa. O cantor,

\footnotetext{
${ }^{25}$ O OLM 20 pede que o salmo responsorial seja preferencialmente cantado. E este mesmo artigo indica diferentes maneiras concretas de fazê-lo: "O salmo responsorial de preferência seja cantado. Há duas formas de cantar os salmos depois da primeira leitura: a forma responsorial e a forma direta. $\mathrm{Na}$ forma responsorial, que se deve preferir sempre que possível, o salmista ou cantor do salmo cantam as estrofes e toda a assembléia participa com as respostas. Na forma direta, o salmista ou o cantor do salmo cantam o salmo todo, enquanto a assembléia escuta, sem intervir com a resposta; ou então o salmista e os fiéis cantam juntos".

${ }^{26}$ Cf. J.A. JUNGMANN, Missarum sollemnia I, 349. "O nome e o uso relativo existiam já ao certo no Reino dos Francos pelo fim do século VIII. Os antifonários manuscritos (francos) de tal época publicados por HESBERT usam regularmente a escritura Grad. ou Resp. grad. - Mas também em Roma para o nosso canto, que os antigos Ordines chamavam simplesmente responsorium, é já transmitida em comum acordo esta mesma denominação no Gregoriano de Adriano, se bem que em redação diversa: (sequitur) gradale, gradalis, gradalem; H. LIETZMANN, Das Saramentarium Gregorianum nach dem Aachener Urexemplar: Münster, 1921, n. I" (J.A. JUNGMANN, Missarum sollemnia I, p. 349 , nota 75 ).
} 
o coro e os instrumentistas, cada um a seu modo, "con-celebram" a eucaristia da assembléia, a qual é presidida pelo sacerdote. E cada um destes "con-celebrantes" realiza um serviço insubstituível no conjunto da celebração.

Os ministros do canto sacro realizam um verdadeiro ministério litúrgico [cf. IGMR 103; Vicesimus quintus annus, n. 1027]. Neste sentido a própria MS vai pedir que haja um ou dois cantores que proponham e sustentem o canto do povo ${ }^{28}$. E a IGMR 116, como vimos mais acima, indica na missa a presença de um cantor, um acólito e um leitor que assistam o sacerdote celebrante. No momento da oração dos fiéis, "as intenções ou invocações podem ser cantadas pelo diácono, cantor ou outro ministrante idôneo ..." [Inter Oecumenici, n. 56 $6^{29}$; cf. IGMR 71].

Também a schola cantorum realiza um importante serviço litúrgico. A Dominicae cenae, n. 10, chega a louvar o fato de que ultimamente, graças às possibilidades introduzidas pela renovação pós-conciliar, cresce o número dos que tomam parte ativa nas celebrações: "Nascem grupos de leitores e de cantores, mais freqüentemente ainda "scholae cantorum», masculinas e femininas ...". Todavia, superando uma visão que tendia a separar a schola da assembléia dos fiéis, alguns textos esclarecem que a schola cantorum faz parte integrante da assembléia dos fiéis, o que deve ser demonstrado mesmo a nível espacial:

A posição da «Schola» e do órgão deve ressaltar claramente que os cantores e o organista fazem parte da assembléia dos fiéis; e seja tal que estes possam realizar o seu ofício litúrgico do modo mais idôneo [Inter Oecumenici, 97;

cf. MS 23; IGMR 312].

O já nosso conhecido n. 13 da MS vai dar um lugar particular, pelo ofício que realiza na celebração, também à Schola cantorum [cf. ainda n. 19]. Esta, porém, deve promover a participação dos fiéis nos cantos executados [cf. MS 20, 53; IGMR 103], e proferir de maneira clara e inteligível as suas partes [cf. MS 26]. Mas chama-se ainda a atenção para a necessidade de

\footnotetext{
${ }^{27}$ JOÃO PAULO II, Carta apostólica Vicesimus quintus annus, de 4 de dezembro de 1988 (no $25^{\circ}$ aniversário da Sacrosanctum Concilium), AAS 81 (1989) 898-918; Notitiae 25 (1989) 387-404.

28 "Seja providenciado, especialmente onde não se tenha possibilidade de instruir nem uma "schola» modesta, que exista pelo menos um ou dois cantores, convenientemente instruídos que pelo menos proponham cantos simples para a participação do povo e guiem e sustentem oportunamente os fiéis" [MS 21]. A isso se une também a IGMR: "Convém que haja um cantor ou regente de coro para dirigir e sustentar o canto do povo. Mesmo não havendo um grupo de cantores, compete ao cantor dirigir os diversos cantos, com a devida participação do povo" [IGMR 104].

${ }^{29}$ Cf. SAGRADA CONGREGAÇÃO DOS RITOS, Instrução Inter Oecumenici, de 26 de setembro de 1964 ( $1^{\mathrm{a}}$ instrução para a devida aplicação da SC), nn. 33, 56, AAS 56 (1964) 877-900.
} 
formação musical técnica da schola, sem que se esqueça de insistir na necessária formação litúrgica e espiritual:

Além da formação musical, seja dada também aos membros da «schola cantorum» uma adequada formação litúrgica e espiritual, de modo que da exata execução de seu ofício litúrgico derivem não só o decoro da ação sagrada e a edificação dos fiéis, mas também um verdadeiro bem espiritual para os próprios cantores [MS 24].

Naquilo que se refere aos instrumentistas e a seus instrumentos, recomendações semelhantes podem ser encontradas nos textos. Estes devem ocupar um lugar tal a sustentarem o canto e serem ouvidos por todos:

O órgão e outros instrumentos musicais legitimamente aprovados sejam colocados em tal lugar que possam sustentar o canto da escola e do povo e possam ser facilmente ouvidos por todos, quando tocados sozinhos [IGMR 313].

Recorda-se ainda que: "Também nas Missas com crianças «os instrumentos musicais podem ser de grande utilidade», especialmente se tocados pelas próprias crianças ..." [Diretório para missas com crianças 32]. E como a natureza das partes presidenciais exige que todos as escutem, "... enquanto o sacerdote as profere, não haja outras orações nem cantos, e calem-se o órgão ou qualquer instrumento" [IGMR 32].

O canto litúrgico é a forma suprema da veiculação da palavra e da oração presidencial, dos ministros e da assembléia. Por isso, no tempo de plenitude cristã, que é a Páscoa, a Igreja, no Ofício de Leituras, faz recordar estas inspiradas palavras de Santo Agostinho, bispo, quando diz:

Cantai com a voz, cantai com o coração, cantai com os lábios, cantai com a vida: Cantai ao Senhor Deus um canto novo. Queres saber o que cantar a respeito daquele a quem amas? Sem dúvida, é acerca daquele a quem amas que desejas cantar. Queres saber então que louvores irás cantar? Já o ouviste: Cantai ao Senhor Deus um canto novo. Que louvores? Seu louvor na assembléia dos fiéis. O louvor de quem canta é o próprio cantor. Quereis cantar louvores a Deus? Sede vós mesmos o canto que ides cantar. Vós sereis o seu maior louvor se viverdes santamente ${ }^{30}$.

\section{e) Comentadores, mestres de celebrações}

Muito embora a Constituição litúrgica peça que: "Os ritos resplendam por sua nobre simplicidade; sejam claros por brevidade e evitem inúteis repetições; sejam adaptados à capacidade de compreensão dos fiéis e geralmente não tenham necessidade de muitas explicações" (SC 34), o ministé-

${ }^{30}$ Sermo 34,1-3.5-6: CCL 41,424-426. 
rio litúrgico do comentador foi colocado sob nova luz exatamente a partir da reforma do Vaticano II. E isso tem uma explicação. Quando num passado não muito distante a liturgia da missa interessava quase exclusivamente ao sacerdote celebrante e aos ministros, também não se pensava na utilidade do comentador na assembléia eucarística. Quando porém esta mesma celebração começa a envolver toda a assembléia e ser como que o produto direto da inteira comunidade, ministros e fiéis, o papel do comentador ganha importância pela ação que no culto é capaz de desenvolver.

A função do comentador ${ }^{31}$ liga-se diretamente à promoção da participação ativa, consciente e plena dos fiéis na missa. Assim eles também ocupam lugar particular na celebração [cf. MS 13] na medida em que cumprem um verdadeiro ministério litúrgico [cf. Vicesimus quintus annus 10]. Na realização de sua tarefa devem proferir as partes de modo claro e inteligível [cf. MS 26], fazendo jus à sua missão de condutor e discreto guia da celebração.

A IGMR, elencando a função de vários ministros, indica o comentador como aquele que:

dirige aos fiéis breves explicações e exortações, visando a introduzi-los na celebração e dispô-los para entendê-la melhor. Convém que as exortações do comentarista sejam cuidadosamente preparadas, sóbrias e claras. Ao desempenhar sua função, o comentarista fica em pé em lugar adequado voltado para os fiéis, não, porém, no ambão [IGMR 105b].

Com explicações breves, sóbrias e bem preparadas, o comentador vai introduzindo os fiéis no espírito autêntico da celebração, a fim de que todos compreendam melhor aquilo que se celebra. Esclarece-se também que o lugar de onde ele dirige tais exortações não é o ambão. Essa mesma intuição se faz presente no texto do OLM que, de certa forma, retoma a IGMR, esclarecendo-a mais ainda:

Também o comentador realiza um verdadeiro ministério litúrgico quando, de um lugar adequado, propõe à comunidade dos fiéis explicações e admoestações oportunas, claras, sóbrias, cuidadosamente preparadas, normalmente escritas e antecipadamente aprovadas pelo celebrante (cf. IGMR 105) [OLM 57].

31 Sobre a função do comentador na assembléia, veja: A.-M. ROGUET, "Le «Commentateur»", La Maison Dieu 60 (1959) 80-98; A. DUVAL, "Le Concile de Trente et les origines du "commentateur»", La Maison Dieu 61 (1960) 41-47; P. TENA, "El comentador, un elemento clave del movimento litúrgico actual", Phase 1 (1961) 1-5; ID., “Cómo si prepara un comentador", Phase 2 (1962) 133-137; G. OGGIONI, "La partecipazione attiva dei fedeli all'offerta del Sacrificio Eucaristico (II): Il commentatore", Ambrosius 39 (1963) 118-123; L. BOUYER, "Faut-il encore un commentateur?", La Maison Dieu 84 (1965) 55-73. 
Mas o OLM tem presente também que as admonições antes das leituras, que cabem principalmente a quem preside, e tem por finalidade ajudar a assembléia a compreender melhor a Palavra de Deus, "... podem ser confiadas também a outros, por exemplo, ao diácono ou ao comentarista" [OLM 42]. E nas missas sem diácono, o comentador pode proferir as intenções da oração dos fiéis ${ }^{32}$.

A função do comentador não é explicar exaustivamente o desenvolver-se da celebração, mesmo porque os ritos reformados a partir do Concílio em si são já fáceis e evidentes. Tarefa sua é despertar a atenção dos fiéis para determinados elementos do culto, é aguçar o espírito do povo da assembléia para a participação consciente e plena. Suas exortações não são feitas a qualquer tempo, mas em momentos significativos do culto. No início da missa o comentador introduz os fiéis no conjunto do ato celebrativo, antes das leituras chama a atenção para a Palavra de Deus que será proclamada e no final faz a ligação entre culto e vida, para que o povo possa colocar na prática da existência aquilo que na assembléia foi evocado. E tudo isso deverá ser feito com comentários breves e incisivos. Outros momentos podem merecer ainda a intervenção do comentador, mas que não sejam numerosos, exatamente porque o importante é a celebração, não o comentário da celebração.

Uma figura de certo relevo em se tratando de celebrações maiores, mas que quase não é citada nos textos, é a do mestre de celebrações ${ }^{33}$. Somente uma passagem da IGMR trata deste ministério. No contexto em que o documento trata dos ministérios particulares, assim lemos:

É conveniente, ao menos nas igrejas catedrais e outras igrejas maiores, que haja algum ministro competente ou mestre de cerimônias, a fim de que as ações sagradas sejam devidamente organizadas e exercidas com decoro, ordem e piedade pelos ministros sagrados e pelos fiéis leigos [IGMR 106].

Este "ministro competente" de que trata o texto, ou mestre de celebrações, não deve ser visto por nós como a encarnação do enrijecimento e da inflexibilidade na celebração, como muitas vezes, com ou sem razão, foi tachado. Ele não é e nem deveria ser aquele que tolhe a liberdade e espontaneidade dos ministros e dos fiéis, impedindo a sua livre expressão e transformando o culto em algo tenso e formal, exatamente o contrário do que deseja a reforma litúrgica do Concílio Vaticano II. O mestre de celebrações, pelo contrário, deveria ser o que ajuda, conduz e orienta todos os que tomam parte no ato sagrado a exprimirem bem e ordenadamente através de gestos, movimentos e palavras, aquilo que intensamente celebram. $\mathrm{O}$

${ }^{32}$ Nas Missas sem diácono, este ofício seja confiado a um ministrante idôneo (por ex., o comentador)... [De oratione communi seu fidelium, Fascículo do "Consilium", de 17 de abril de 1966 (sobre a oração comum ou dos fiéis), n. 8].

${ }^{33}$ Sobre a função do mestre de cerimônias na liturgia, veja: B. CALLE, "Un grand méconnu, le cérémoniaire", Notitiae 18 (1982) 119-120. 
mestre de celebrações se coloca, assim, a serviço da beleza da ação litúrgica. Mas não se trata somente de conduzir a execução dos ritos; é preciso que este promova e provoque aquela beleza interior, espiritual, que põe a criatura em contato íntimo e direto com o seu Criador, tanto durante, como para além do culto.

Assim, o mestre de celebrações zela pela "gramática da ação ritual", fazendo com que o bom ritmo pervada toda a ação de culto ${ }^{34}$. Para isso ele coordena as diferentes ações simbólicas, a unidade das seqüências rituais e as várias interferências dos ministros que agem ao longo da celebração.

O próprio artigo 106 da IGMR trata de forma muito positiva desta função, porquanto ajuda os ministros a viverem a celebração com decoro, ordem e piedade. Desta forma numa assembléia maior, na qual intervêm muitos ministros, não se pode dispensar alguém (chamemo-lo como quisermos) que possa prestar aí o serviço da organização, sempre em vista da intensificação da vivência e da participação interior e exterior de todos.

\section{f) Outras funções na assembléia eucarística}

Podemos tratar ainda de outras funções na assembléia eucarística, como por exemplo, dos ministros extraordinários da comunhão, dos organizadores de procissões e coletas e daqueles encarregados da recepção dos irmãos à porta da igreja e dos que cuidam dos idosos e crianças. O certo é que, quanto mais uma assembléia participa com intensidade da celebração, tanto mais se revela como toda ministerial, descobrindo e acrescentando o número de serviços que aí deve oferecer.

A Instrução Immensae caritatis ${ }^{35}$, falando do serviço dos ministros extraordinários da comunhão, dá normas para o seu exercício. Naquilo que concerne à missa, o citado documento permite a ação deste ministério "... por motivo de um grande concurso de fiéis ou por qualquer particular dificuldade na qual venha a encontrar-se o celebrante" [n. 1]. E quanto a

\footnotetext{
${ }^{34}$ Podemos conceber o rito litúrgico como linguagem em analogia com outras linguagens, particularmente com a língua falada, ambos se articulando numa cadeia de significantes. Daí a existência de uma verdadeira gramática da ação ritual, composta por uma sintaxe ritual (relação entre símbolo e símbolo, entre rito e rito numa mesma celebração), por uma morfologia ritual (que se ocupa dos ritos menores enquanto distintos de ritos complexos chamados rituais), por uma prosódia ritual (que trata do ritmo celebrativo ou do acento no processo ritual: os ritos mais destacados, o ponto culminante, as partes ascendentes e descendentes) e por uma retórica e estilística ritual (que se interessam pela relação, não de ritos dentro do ritual, mas da maneira como os rituais de uma dada celebração se relacionam entre si) (cf. L. MALDONADO, "Como se celebra. Elementos e dinamismo da celebração", in D. BOROBIO (org.), A celebração na Igreja I. Liturgia e sacramentologia fundamental, São Paulo: Loyola, 1990, pp. 226-227.

${ }^{35}$ SAGRADA CONGREGAÇÃO PARA A DISCIPLINA DOS SACRAMENTOS, Instrução Immensae caritatis, de 29 de janeiro de 1973 (maiores facilidades de receber a santa comunhão), AAS 65 (1973) 264-271; Notitiae 9 (1973) 157-164.
} 
quem pode exercer tal ministério, o mesmo documento a seguir, mesmo deixando a juízo do ordinário do lugar, propõe a seguinte ordem: "leitor, aluno de seminário maior, religioso, religiosa, catequista, fiel: homem ou mulher" [Immensae caritatis, n. 1,IV]. A propósito, porém, veja-se o quanto vem ultimamente determinado na última edição da IGMR [cf. nn. 191192] e na Instrução Redemptionis Sacramentum [cf. nn. 154-160].

Quanto aos que organizam coletas e procissões e servem como recepcionistas na igreja, cumprem tarefas muito úteis no conjunto da celebração da assembléia. A Liturgicae instaurationes ${ }^{36}$ indica tais funções como trabalhos que podem ser realizados também por mulheres (n. 7e). E a IGMR elenca-os entre os serviços próprios de ministros que permanecem fora do presbitério [cf. IGMR 105c-d]. O ministério das coletas e procissões é bastante realizado na grande maioria de nossas comunidades, mas não aquele importante serviço de recepcionista. São raras as comunidades que já despertaram para esta necessidade que tanto bem proporcionam às comunidades. Além disso, há ainda o serviço das crianças, que de certa forma é tratado em todo o Diretório para missa com crianças. Gostaríamos somente de destacar aí um artigo que sobre isso assim se expressa:

As crianças que ainda não podem ou não querem participar da missa, poderão ser eventualmente conduzidas, durante a celebração e por auxiliares da paróquia, a um lugar adaptado a elas, separado da igreja, e serem reconduzidas à igreja no final do rito, para receberem com os outros a bênção [Diretório para missas com crianças 16].

\section{A mulher e sua função na assembléia}

A questão da função litúrgica da mulher na assembléia de culto se insere no problema bem mais complexo do lugar que esta ocupa na Igreja como um todo ${ }^{37}$, e deita raízes na ampla história eclesial.

Com efeito, desde a origem do cristianismo encontramos mulheres desempenhando importantes papéis no conjunto da vida cristã, muito embora nenhuma exerça aí o encargo de direção da comunidade ${ }^{38}$. A. Keerkvoorde ${ }^{39}$,

${ }^{36}$ SAGRADA CONGREGAÇÃO DO CULTO DIVINO, Instrução Liturgicae instaurationes, de 5 de setembro de 1970 ( $3^{\text {a }}$ Instrução para a aplicação da Constituição Sacrosanctum Concilium), AAS 62 (1970) 692-704.

${ }^{37}$ Importa ter presente aqui a Carta Apostólica Mulieris dignitatem, de JOÃO PAULO II, a qual inicia pretendendo tratar de forma positiva da presença ativa da mulher na Igreja e na sociedade hodierna: IOANNES PAULUS II, Epistula apostolica Mulieris dignitatem, 15 augusti 1988 (sobre a dignidade e vocação da mulher por ocasião do ano mariano): AAS 80 (1988) 1653-1729.

${ }^{38}$ Cf. R. GOLDIE, "Mulher", in Dicionário de Liturgia, São Paulo: Paulinas, 1992, p. 801.

${ }^{39} \mathrm{Cf}$. A. KEERKVOORDE, "Elementos para uma teologia do diaconato", in G. BARAÚNA (org.), A Igreja do Vaticano II, Petrópolis / Rio de Janeiro: Vozes, 1965, p. 929. 
bem como outros autores, chamara a atenção para o fato de na Tradição Apostólica encontrarmos mencionadas, entre as três grandes ordens e os leigos, as chamadas "ordens intermediárias", que incluíam também as viúvas e as virgens ${ }^{40}$. E que no Oriente também havia as diaconisas, exercendo função relevante no conjunto da Igreja ${ }^{41}$. Todas elas são citadas na Escritura e foram instituídas em «ordem», muito embora nunca a tradição as tenha feito participarem do clero e da hierarquia propriamente dita. Mas estes poucos dados históricos já nos indicam suficientemente como as mulheres exerciam na Igreja antiga um significativo ministério ${ }^{42}$. E podem também induzir a reflexão eclesiástica atual à necessidade de repensar o papel que deve desempenhar a mulher na Igreja a partir do hoje ${ }^{43}$.

\footnotetext{
40 “As viúvas que já não são jovens têm a sua 'ordem' (viduatus), mas a viuvez não é função: é estado de vida, elevado, na ordem, a ideal ascético e organizado. As viúvas não são 'ordenadas', mas 'inscritas' ou 'constituídas'; não prestam serviço litúrgico, mas dedicam-se à oração, praticam o jejum; visitam os enfermos e fazem-lhes uma imposição das mãos, mas não se trata de função; é intervenção de tipo carismático, privilégio da vida santa. No início, as viúvas serviam como critério de imitação para as virgens (no séc. II encontramos as «virgens chamadas viúvas»). Posteriormente, foram associadas às próprias virgens. Desde o fim do séc. IV, existe o rito de consagração das virgens, que confere estatuto oficial na Igreja e associa as virgens, sob certo ponto de vista, ao clero; mas não pode ser isto confundido com um rito de ordenação. Sabemos, enfim, que sequer as abadessas, que na Idade Média exerciam poderes de jurisdição, jamais tiveram poderes inerentes ao sacramento da ordem" (R. GOLDIE, "Mulher", art. cit., p. 802).

${ }^{41}$ Sobre este assunto convém ter presente o abrangente estudo de A.G. MARTIMORT, Le diaconesse. Essai historique, Roma: C.L.V. - Edizioni Liturgiche, 1982 (= Bibliotheca «Ephemerides Liturgicae» «Subsidia» 24). Segundo este autor, os primeiros séculos silenciaram quanto à existência de diaconisas. Neste sentido, Lc 8,2-3; Rm 16,1-22 e 1Tm 3,11; 5,9-10 não se referem a um verdadeiro e próprio ministério diaconal em sentido estrito. Somente no $\mathrm{III}^{\circ}$ século e na parte mais oriental do Império romano é que começamos a ter notícias delas, sendo a Didascália dos Apóstolos o primeiro documento a nomeá-las. Mais tardiamente surgem diaconisas nas Igrejas de língua grega e em outras Igrejas da região oriental do Império, para entre os séculos X e XI desaparecerem por completo no Oriente. A respeito deste assunto, consulte-se ainda: R. GRYSON, Le ministère des femmes dans l'Église ancienne, Gembloux, 1971; H. FROHNHOFEN, "Weibliche Diakone in der frühen Kirche", Stimen der Zeit 204 (1986) 269-278; P. JOUNEL , "As ordenações", in A.G. MARTIMORT (org.), A Igreja em oração 3: Os sacramentos, Petrópolis: Vozes, 1991, pp. 125-162; S. PARENTI, "In Oriente", in AA.VV., Scientia Liturgica. Manuale di Liturgia. IV. Sacramenti e sacramentali, Casale Monferrato: Piemme, 1998, pp. 219-229.

${ }^{42}$ Uma visão histórica da função desenvolvida pela mulher na Igreja é ainda fornecida, além das obras já citadas acima, por: J. DANIÉLOU, "Le ministère des femmes dans l'Église ancienne", La Maison Dieu 61 (1960) 70-96; H. VAN DER MEER, Sacerdozio della donna?, Brescia, 1971; E. LODI, "Ministero della donna: problematica attuale. Rassegna bibliográfica”, Rivista Liturgica 63 (1976) 677-689; G. REMIS, La consagración de la mujer en las liturgias occidentales, Roma: C.L.V — Edizioni Liturgiche, 1990 (= Bibliotheca «Ephemerides Liturgicae» «Subsidia» 52).

${ }^{43}$ A propósito, consulte: M. ALCALÁ, La mujer e los ministerios en la Iglesia. Del Vaticano II a Pablo VI, Salamanca, 1982 (= «Nueva Alianza» 80); M.L. PETRAZZINI, "La diakonia della donna nella chiesa”, Rivista Liturgica 60 (1973) 341-359; 512-532.
} 
Naquilo que se refere aos nossos documentos, este futuro não aparece muito claro. Os textos que tratam da função da mulher na liturgia da assembléia eucarística, quando não descrevem o que elas não podem realizar aí, são unânimes em inseri-las, quando muito, em ofícios litúrgicos periféricos.

Na Instrução Musicam sacram, primeiro a se referir à ação da mulher na liturgia eucarística no pós-concílio, tratando dos membros da schola cantorum, dirá que esta pode ser composta "... seja de homens e rapazes, ou de só homens ou de só rapazes, seja de homens e mulheres, e também, onde a situação realmente o exija, de só mulheres" [MS 22]. Nenhum problema, portanto, na admissão de mulheres nos coros musicais. $\mathrm{O}$ artigo sucessivo, porém, quanto ao lugar da schola, chama a atenção que "Quando a «schola cantorum» compreender também mulheres, seja colocada fora do presbitério" [n. 23]. As mulheres, assim, naquela época de publicação desta Instrução, não eram admitidas na área do presbitério e, assim, não podiam participar de grupos que se reunissem naquele local, situação superada por documentos posteriores.

Em seguida a Actio pastoralis, texto já citado por nós quando analisávamos a função do leitor, dando normas para missas em grupos particulares, vai também rapidamente dizer algo sobre a atuação da mulher nestas assembléias: "As leituras que precedem o Evangelho poderão ser lidas por qualquer dos participantes (homem ou mulher) ..." [n. 6f]. Vemos aqui que às mulheres é concedido, mas só nas missas para grupos particulares, a proclamação das leituras que precedem o evangelho. Cinco meses depois era publicada a Instrução Constitutione apostolica «Missale romanum ${ }^{44}$ », que tinha a finalidade de facilitar a gradual aplicação da constituição Missale romanum de Paulo VI. E nesta se recorda que cabe às Conferências Episcopais emanar normas que a IGMR reconhece de sua competência, como “... a faculdadez de permitir a mulheres a proclamação das leituras bíblicas antes do Evangelho (cf. IGMR 21)" [n. 8].

De fato, numa determinada parte da IGMR, na sua versão anterior que acompanhava as duas primeiras edições do Missal Romano, assim líamos:

Todas as funções inferiores às do diácono poderão ser exercidas por leigos do sexo masculino, mesmo que não tenham sido instituídos para isso. As funções fora do presbitério poderão também ser confiadas a mulheres, segundo o prudente parecer do reitor da igreja. A Conferência Episcopal pode permitir que mulher idônea faça as leituras que precedem o Evangelho e proponha as intenções para a oração dos fiéis (cf. Liturgicae instaurationes

${ }^{44}$ SAGRADA CONGREGAÇÃO DO CULTO DIVINO, Instrução Constitutione Apostolica «Missale Romanum», de 20 de outubro de 1969 (sobre a aplicação progressiva da Constituição apostólica Missale Romanum), AAS 61 (1969) 749-753; Notitiae 5 (1969) 418-423. 
7) e determinar mais exatamente o lugar apto donde anuncie a Palavra de Deus na assembléia litúrgica [IGMR, antiga versão, n. 70].

Aqui se reafirmava a proibição de mulheres subirem ao presbitério, embora a elas fosse concedido exercer funções fora daquele espaço.

Hoje, porém, esta restrição foi superada.

As funções litúrgicas, que não são próprias do sacerdote ou do diácono e das quais se trata acima (n. 100-106), podem ser confiadas também pelo pároco ou reitor da igreja a leigos idôneos ${ }^{45}$ e escolhidos com bênção litúrgica ou designação temporária. Quanto à função de servir ao sacerdote junto ao altar, observem-se as normas dadas pelo Bispo para sua diocese [IGMR 107].

A Immensae caritatis, num texto já tratado quando se falou dos ministros extraordinários da comunhão eucarística, enumera a mulher leiga no grupo dos que podem exercer este ministério na Igreja:

A designação da pessoa idônea a que se refere os nn. I e II, se fará tendo presente a seguinte ordem, que porém pode ser mudado segundo o prudente juízo do ordinário do lugar: leitor, aluno de seminário maior, religioso, religiosa, catequista, fiel: homem ou mulher [n. 1,IV].

A leiga mulher é felizmente elencada entre os possíveis candidatos ao ministério extraordinário da comunhão, embora seja infelizmente enumerada em último lugar.

Já um artigo da Liturgicae instaurationes procura descrever amplamente o que a mulher pode e não pode realizar na assembléia eucarística, segundo as normas litúrgicas da Igreja. Algumas partes deste número já foram estudadas acima, quando enfocávamos os outros ministérios. Pela importância da afirmação para o tema do ministério da mulher na liturgia, apresentaremos a seguir todo o artigo:

Segundo as normas litúrgicas da Igreja, não é permitido às mulheres (jovens, esposas, religiosas) servir o sacerdote no altar, nem mesmo em igrejas, casas, conventos, colégios e institutos femininos. Segundo as normas dadas nesta matéria, é lícito às mulheres: a) proclamar as leituras, exceção feita ao Evangelho. Exerçam este ofício servindo-se dos instrumentos técnicos modernos, de modo que possam ser claramente ouvidas por todos. As Conferências Episcopais podem determinar o lugar adaptado, do qual as mulheres anunciarão a Palavra de Deus na assembléia litúrgica; b) propor as intenções da oração universal; c) guiar o canto da assembléia e tocar o órgão ou outros instrumentos permitidos; d) ler os avisos ou as exortações, para levar os fiéis a uma maior compreensão do rito; e) exercer a serviço da

${ }^{45}$ Cf. PONT. CONS. DE LEGUM TEXTIBUS INTERPRETANDIS, Responsio ad propositum dubium circa can. 230 § 2 , AAS 86 (1994) 541-542, aqui p. 541. 
assembléia dos fiéis algumas tarefas, que geralmente são confiadas às mulheres, por ex., receber os fiéis na porta das igrejas e fazê-los acomodarse nos lugares preparados para eles, organizar as procissões, realizar as coletas de dons nas igrejas [n. 7].

Após proibir qualquer mulher servir ao sacerdote no altar, o texto descreve o que lhe é permitido na assembléia litúrgica. Apesar da quantidade de funções elencadas, notamos porém que muitas não passam de ofícios periféricos, o que demonstra o quanto a Igreja precisava ainda evoluir no reconhecimento do papel litúrgico da mulher na assembléia. Estas mesmas observações serão ainda sinteticamente repetidas dez anos depois pela Inaestimabile donum 18, que se apóia no mesmo texto da Liturgicae instaurationes apresentado acima ${ }^{46}$.

Todavia a Vicesimus quintus annus chega a apontar alguma luz para o futuro, quando declara que o esforço de renovação litúrgica deverá ainda responder às novas exigências surgidas neste nosso tempo. E cita entre eles a questão das funções litúrgicas que na celebração podem ser confiadas a leigos, homens e mulheres. Conquanto a SC não trate de tais questões, dá porém princípios gerais para a coordenação e promoção de toda a vida litúrgica [cf. Vicesimus quintus annus 17].

Atualmente a Igreja tem permitido, a juízo do bispo do lugar, a participação da mulher em certos serviços junto ao altar, podendo ajudar como acólitas, conforme observamos acima na IGMR 107, o que recebeu ultimamente confirmação na Instrução Redemptionis Sacramentum [cf. n. 47].

A questão ministerial da mulher na ação cultual da Igreja permanece, portanto, aberta. Pouco se fez e muito ainda temos a fazer sobre este delicado assunto. Faz-se urgente, por exemplo, empreender toda uma investigação histórica sobre a função da mulher na vida da Igreja primitiva, capaz de dar maior clareza a esta questão no hoje da Igreja. Necessário é ainda refletir teologicamente sobre a problemática ministerial da mulher como resposta de uma Igreja que se insere responsavelmente nas estruturas da sociedade e nas preocupações do mundo de hoje. Não menos urgente é a tarefa de repensar as concretas e atuais atribuições dadas às mulheres em nossas liturgias, em especial, na liturgia eucarística, para se chegar a descobrir outros espaços litúrgicos de importância que podem ser ocupados por elas na assembléia. Nada disso, porém, poderá ser realizado se não tivermos o coração aberto para acolhermos outras formas ministeriais novas que podem surgir no hoje, como uma resposta do Espírito à nossa incessante procura de fidelidade a Cristo e à situação dos irmãos e irmãs nestes novos tempos da Igreja.

\footnotetext{
46 "Como é conhecido, são várias as partes que a mulher pode exercer na assembléia litúrgica, entre as quais a leitura da Palavra de Deus e a proclamação das intenções na oração dos fiéis. Não são permitidas, porém, a mulheres as funções de acólito (ministrante)" [Inaestimabile donum 18].
} 
Vimos, pois, que a grande quantidade de ministros no culto da assembléia manifesta a Igreja toda ministerial. Tal ministerialidade, porém, é hierarquicamente ordenada, pois na assembléia cada um tem um papel definido. Também a hierarquia não quer dizer honra, nem supremacia de uns sobre os outros, mas dedicado serviço aos irmãos, a exemplo da diaconia de Cristo. Importa observar ainda que esta imensa riqueza de ministérios e serviços nunca nos deve fazer esquecer que o verdadeiro sujeito da celebração é sempre a assembléia dos fiéis ${ }^{47}$, pois é toda a assembléia que celebra o culto litúrgico ao Senhor, sob a presidência do sacerdote.

\section{Assembléia litúrgica sem o sacerdote}

Embora este seja um tema que não nos importa diretamente, já que nos propusemos refletir principalmente sobre as assembléias reunidas em vista da celebração eucarística, acreditamos que seja útil não esquecer, dadas as suas relações com a eucaristia, seu número e importância atual, a realidade daquelas assembléias que se reúnem para o culto, em especial no domingo, na ausência do presbítero ${ }^{48}$. Trata-se de um fenômeno relativamente novo na Igreja, que deita raízes na falta de vocações sacerdotais. Todavia, de tema que interessava prevalentemente os missionários nas terras consideradas de missão ${ }^{49}$, ele começa a ser importante também em muitos países tidos hoje como já cristianizados ${ }^{50}$.

${ }^{47}$ Cf. CONFERENZA EPISCOPALE ITALIANA, "Il rinnovamento liturgico in Italia. Nota pastorale a vent'anni della Costituzione conciliare «Sacrosanctum Concilium»", Rivista Liturgica 70 (1983) 578-592, aqui p. 583.

${ }^{48}$ Como aprofundamento neste tema, veja: J. KÉMÉRER, "Celebração da Palavra de Deus sem sacerdote", in G. BARAÚNA (org.), A sagrada liturgia renovada pelo Concílio, Petrópolis: Vozes, 1964, pp. 507-514; "Brasilia. Relatório sobre os ministérios litúrgicos exercidos por leigos", Notitiae 11 (1975) 263-268; M. BRULIN, "Assemblées domenicales en absence de prêtre. Situation en France et enjeux pastoraux", La Maison Dieu 130 (1977) 80-113; P.F. BRADSHAW, "Modèles de ministère: le rôle des laïcs dans la liturgie", La Maison Dieu 154 (1983) 127-150; P. MARINI, "La eventual presidencia liturgica de los laicos en ausencia del sacerdote", Phase 27 (1987) 113-128.

${ }^{49} \mathrm{~J}$. Kémérer, fiel à linguagem ainda comum em épocas anteriores ao Concílio, descreve tais regiões como "terras de infiéis" e indica como prova da preocupação da Igreja em relação a este tema a sua abordagem nos Congressos Internacionais de Nimega (1959) e Eichstät (1960), imediatamente antes do Concílio Vaticano II (cf. J. KÉMÉRER, "Celebração da palavra de Deus sem sacerdote", art. cit., p. 507).

${ }^{50}$ Só para citar a situação do Brasil, realidade que mais de perto nos interessa, estimase que, pela escassez de sacerdotes e pelas longas distâncias que, por vezes, separam as comunidades cristãs, a grande maioria do povo fiel (mais de $70 \%$ !) se reúne no domingo para a celebração sem a presença do padre. A respeito, veja: Animação da vida litúrgica no Brasil. Elementos de pastoral litúrgica, São Paulo: Paulinas, 1989, nn. 93, 95-97, pp. 34-35 (= Documentos da CNBB, n. 43). Para a questão em outros países, consulte-se: D. SARTORE, “Assembléia sem presbítero", in Dicionário de Liturgia, São Paulo: Paulistas, 1992, pp. 104-108. 
Com a finalidade de dizer uma palavra sobre tais assembléias e regulamentar a sua atuação, a Igreja lançou em 1988 o Diretório sobre as celebrações dominicais na ausência do presbittero ${ }^{51}$. Mas a Constituição litúrgica, sensível a esta questão, já havia pedido que se incentivassem as celebrações da Palavra de Deus sob a direção do diácono ou de outro delegado pelo bispo "sobretudo naqueles lugares onde falta o sacerdote" (SC 35,4).

O primeiro documento pós-conciliar a tratar deste assunto foi a IO, nn. 3739, quando diz que a estrutura de tais celebrações deve se modelar àquela da liturgia da Palavra da missa. As comissões diocesanas são aí convidadas a sugerir e preparar oportunos subsídios para a digna realização de tais celebrações. A seguir a $3^{\text {a }}$ instrução para a reta execução da Constituição litúrgica, Liturgicae instaurationes, volta ao assunto das comunidades sem padre quando ordena expressamente aos seus dirigentes "... a se absterem completamente de proferir a oração eucarística" [LI 6e]. Aqui, como mais tarde também aparecerá no Diretório sobre as celebrações dominicais na ausência do presbitero, se delineia a grande preocupação da Igreja no sentido de evitar toda e qualquer confusão que possa surgir na mente dos fiéis entre a missa e tais celebrações.

O OLM n. 62 vai também tratar rapidamente destas assembléias quando diz que a razão de haver uma única ordenação das leituras no Lecionário da Missa no rito romano é que assim, em todos os lugares e em tempos e dias determinados, todos os fiéis podem escutar as mesmas leituras, também nas comunidades que, por falta de sacerdotes, são dirigidas pelo diácono ou outro leigo designado pelo bispo ${ }^{52}$.

O Diretório sobre as celebrações dominicais na ausência do presbitero apresenta um título sugestivo. Ao chamar o culto de "celebrações na ausência do presbítero" quer mesmo indicar o caráter provisório e substitutivo de tais celebrações. É como se dissesse que estas celebrações estão se realizando agora em caráter excepcional, quase em regime de urgência, por ausência daquele que normalmente deve estar à frente do culto eucarístico da assembléia. No momento, porém, em que novamente o ministro se fará presente, a celebração da eucaristia voltará a ser o ponto alto desta comunidade.

${ }^{51}$ CONGREGAÇÃO DO CULTO DIVINO, Diretório De celebrationibus dominicalibus absente presbytero ("Christi Ecclesia"), de 2 de junho de 1988 (Sobre as celebrações dominicais na ausência do presbitero), Notitiae 24 (1988) 366-378.

52 "Outra razão pela qual se compreende também a conveniência e a utilidade pastoral de um só Elenco das Leituras do Lecionário da missa no rito romano é o fato de que todos os fiéis, principalmente aqueles que por diversos motivos nem sempre participam da mesma assembléia, ouçam, em qualquer parte, em determinados dias e tempos, as mesmas leituras e as meditem aplicando-as às circunstâncias concretas, inclusive naqueles lugares em que, por falta de sacerdote, um diácono ou outra pessoa delegada pelo bispo dirige a celebração da Palavra de Deus (cf. SC 35,4; IO 37-38)" [OLM 62]. 
O documento inicia-se com um proêmio em 7 números. Este, após mostrar a fiel obediência da Igreja ao seu Senhor, expressa na periódica e ininterrupta reunião dominical, que se realiza "desde o dia de Pentecostes até hoje" para a celebração do mistério pascal, enfoca a difícil situação dos nossos dias: escassez de ministros, perseguição contra os cristãos, etc. Segue-se um primeiro capítulo de cunho histórico-pastoral, onde se descrevem o domingo e a sua santificação através do culto da assembléia e os principais elementos requeridos para a realização da assembléia eucarística dominical. O segundo capítulo trata das condições para a celebração dominical na ausência do presbítero, acentuando o caráter de suplência das celebrações, e pedindo que se evite toda confusão entre as reuniões deste gênero e a eucaristia. Para a direção destes cultos seja chamado em primeiro lugar o diácono; na falta deste, o pároco designe leigos, acólitos e leitores instituídos. Faltando também estes, podem ser designados outros leigos, homens ou mulheres, os quais podem exercer tal função por força do seu batismo e confirmação ${ }^{53}$. O terceiro e último capítulo tece uma descrição pormenorizada das duas partes que compõem estas celebrações. Convém sobretudo observar as importantes palavras, tiradas de uma alocução de João Paulo II, e que bem concluem todo o documento:

Todos os cristãos devem se convencer de não poder viver a própria fé, nem participar no modo próprio de cada um, da missão universal da Igreja, sem alimentar-se do pão eucarístico. Igualmente devem convencer-se de que a assembléia dominical é para o mundo sinal do mistério de comunhão, que é a eucaristia ${ }^{54}$.

Tudo isso, porém, não nos deve fazer esquecer a sacramentalidade da Palavra de Deus, a qual produz abundantes frutos toda vez que em comunidade é proclamada, celebrada e explicada, na Eucaristia, na Liturgia das Horas, particularmente no Ofício das Leituras, o qual, por constituição

\footnotetext{
${ }^{53}$ Cf. Diretório sobre as celebrações dominicais na ausência do presbítero, nn. 30-31. Convém observar aqui que quando se trata de determinar a função dos leigos em tais celebrações, o presente Diretório, embora citando o CIC cân. 230 § 3, chama-os de "moderadores", isto é, "guias": "Quando estão ausentes seja o presbítero que o diácono, o pároco designe leigos, aos quais deverá ser confiado o cuidado pelas celebrações, isto é, a condução das orações (moderatio orationis), o serviço da Palavra e a distribuição da santa comunhão" [n. 30]; enquanto que o CIC, de maneira mais forte e aberta os denominará "presidentes": Onde a necessidade da Igreja o aconselhar, podem também os leigos, na falta de ministros, mesmo não sendo leitores ou acólitos, suprir alguns de seus ofícios, a saber, exercer o ministério da Palavra, presidir às orações litúrgicas (precibus liturgicis praeesse), administrar o batismo e distribuir a sagrada Comunhão, de acordo com as prescrições do direito [CIC cân. 230 § 3]. Como bem percebeu o CIC, tais leigos exercem nestas celebrações uma verdadeira e real presidência, muito embora em caráter supletivo.

${ }^{54}$ Allocutio ad quosdam episcopos Galliae sacra limina visitantes (27.03.1987), citado em: Diretório sobre as celebrações dominicais na ausência do presbitero, n. 50. Observe ainda o que ultimamente tem sido assinalado sobre as celebrações realizadas na ausência do presbítero, consultando a Instrução Redemptionis Sacramentum, nn. 162-167.
} 
própria, é uma celebração da Palavra, e também nas demais ações litúrgicas da Igreja. Nesse sentido, o Concílio Vaticano II já recordara:

\begin{abstract}
A Igreja sempre venerou as divinas Escrituras da mesma forma como o próprio Corpo do Senhor, já que, principalmente na Sagrada Liturgia, sem cessar toma da mesa tanto da Palavra de Deus quanto do Corpo do Cristo o pão da vida, e o distribui aos fiéis. [...] Nos livros sagrados, com efeito, o Pai que está nos céus vem carinhosamente ao encontro de seus filhos e com eles fala. E é tão grande o poder e a eficácia que se encerra na Palavra de Deus, que ela constitui sustentáculo e vigor para a Igreja, e, para seus filhos, firmeza da fé, alimento da alma, pura e perene fonte da vida espiritual. Por isto aplicam-se, por excelência, à Sagrada Escritura estas palavras: 'É viva e eficaz a palavra de Deus' $(\mathrm{Hb} 4,12)$ 'que pode edificar e dar herança a todos os santificados' (At 20,32; cf. 1Ts 2,13) [Dei Verbum 21].
\end{abstract}

\title{
Conclusão
}

Alcançamos, pois, o término da segunda e última parte desta nossa pesquisa, que tinha por finalidade principal pôr o leitor em contato com a concepção de ministérios que se extraem dos documentos litúrgicos do magistério universal no pós-concílio. E acreditamos termos adquirido uma visão bastante ampla, diversificada e matizada da íntima relação entre carismas, ministérios e serviços no âmbito da liturgia cristã. Deste modo, tendo por horizonte a pesquisa realizada, acreditamos poder firmar aqui algumas conclusões:

$\left.1^{\circ}\right)$ O ministério é precipuamente um carisma, ou seja, um dom do alto, do Pai, pelo Filho, no Espírito, que torna seu portador apto a desempenhar determinadas atividades, serviços e ministérios em ordem à salvação (cf. 1Cor 12,4ss.). Sendo assim, a Igreja em sua gênese é toda ministerial desde Pentecostes, e não pode se compreender de outro modo. Ela exercita a ministerialidade "ad intra», em funções voltadas para a edificação, a coesão e a manutenção do corpo eclesial e, «ad extra», em funções concomitantes que visibilizam a sua atuação transformadora na sociedade. Embora didaticamente façamos esta distinção, a ministerialidade brota do único dinamismo trinitário, complexo e articulado, que inspira a ministerialidade do culto, da palavra e da coordenação eclesial. Deste modo, os ministérios nascem da contemplação da face do Pai e na diaconia de Jesus Cristo, Servo obediente ao Pai a serviço da humanidade, e se refletem na Igreja e para a Igreja, sacramento de salvação e de libertação da pessoa toda e de todos na única história salvífica (1Jo 1,1-3).

A Igreja apresenta-se toda ministerial desde os seus inícios neo-testamentários e só pode compreender-se deste modo. Ser "toda ministerial" significa que no corpo eclesial cada um é continuamente convidado a pôr em comum os seus dons, ofícios e carismas, para o bem de todos os 
irmãos e sempre em vista da construção do integral Corpo do Senhor. Desta importante tarefa nenhum cristão, ordenado ou não, pode ser dispensado.

$2^{\circ}$ ) Os múltiplos ministérios e serviços litúrgicos, que tão ricamente constituem a Igreja e manifestam a pluralidade de carismas e funções no meio do povo de Deus, jamais podem expressar autoritarismo e manipulação das pessoas e grupos ou denotar honra e privilégio. Tais elementos, tão comuns no nosso mundo, se contrapõem decisivamente ao modus celebrandi, operandi e vivendi do corpo eclesial. Na Igreja, porém, estes serviços nada mais são do que a continuação no tempo e no espaço daquele amor pleno e total com o qual o Senhor Jesus - Servo sofredor - ofereceu a si mesmo, consumando a sua vida por todos. Isso, enquanto indica uma realidade já em fermento no seio da comunidade, não deixa de ser forte alerta no sentido de continuamente recordá-la que a vida à qual é chamada, amadurece num processo lento e contínuo, o que constitui, em definitivo, a sua própria vocação.

$3^{\circ}$ ) Recebendo o impulso da experiência comunitária da Igreja, cada vez mais se firma uma nova terminologia quanto aos ministérios e à sua diversidade. A CNBB, no seu documento Missão e Ministérios dos cristãos leigos e leigas, com muita acuidade, assim apresenta uma nova sistematização da ministerialidade:

Na reflexão teológica e pastoral, têm-se distinguido os seguintes grupos de ministérios: a) ministérios simplesmente "reconhecidos" (às vezes, impropriamente, chamados ministérios "de fato"), quando ligados a um serviço significativo para a comunidade, mas considerado não tão permanente, podendo vir a desaparecer, quando variarem as circunstâncias; b) ministérios "confiados", quando conferidos ao seu portador por algum gesto litúrgico simples ou alguma forma canônica; c) ministérios "instituídos", quando a função é conferida pela Igreja através de um rito litúrgico chamado "instituição"; d) ministérios "ordenados" (também chamados apostólicos ou pastorais), quando o carisma é, ao mesmo tempo, reconhecido e conferido ao seu portador através de um sacramento específico, o sacramento da Ordem, que visa a constituir os ministros da unidade da Igreja na fé e na caridade, de modo que a Igreja se mantenha na tradição dos Apóstolos e, através deles, fiel a Jesus, ao seu Evangelho e à sua missão. O ministério ordenado, numa eclesiologia de totalidade e numa Igreja toda ministerial, não detém o monopólio da ministerialidade da Igreja. Não é, pode-se dizer, a "síntese dos ministérios", mas o "ministério da síntese". Seu carisma específico é o da presidência da comunidade e, portanto, da animação, coordenação e - com a indispensável participação ativa e adulta de toda a comunidade - do discernimento final dos carismas ${ }^{55}$.

${ }^{55}$ CONFERÊNCIA NACIONAL DOS BISPOS DO BRASIL, Missão e ministério dos cristãos leigos e leigas, São Paulo: Paulinas, 1999, n. 87, pp. 69-70 (= Documentos da CNBB, n. 62). 
$4^{\circ}$ ) A Igreja, portanto, não pode existir sem ministros, pois eles definem a sua própria identidade, desenhando em definitivo a sua fisionomia. Quanto mais profunda for a participação de todo o povo de Deus numa assembléia celebrativa, tanto mais ministérios se farão aí necessários, manifestando assim a Igreja como comunidade verdadeiramente participativa, onde cada um é chamado a dar a sua contribuição, na construção do Reino de Cristo, para o bem de todo o povo de Deus. Além do mais, os ministérios litúrgicos sempre se desdobram nos ministérios da caridade, da justiça, que visam a construção de um mundo mais justo e mais fraterno. E, por isso mesmo, a Igreja sempre criou múltiplas estruturas de serviço caritativo segundo os contextos sócioeclesiais e suas exigências.

$5^{\circ}$ ) Assistimos atualmente a uma nova consciência sobre o papel do laicato na Igreja, elemento que recebeu forte promoção da Constituição Gaudium et Spes, e que também levou a uma eclosão da presença do leigo nos ministérios e serviços eclesiais (evangelização, serviços da caridade, teologia, catequese, diversas pastorais) e, particularmente, nos ministérios litúrgicos. Nas muitas Igrejas da Ásia, África e América Latina, constatase cada vez mais a emergência de ministérios espontâneos com uma abrangência litúrgica e sempre protagonizados por mulheres e homens que com dedicação, afinco e perseverança levam adiante a edificação das comunidades cristãs, vivenciando o ano litúrgico em momentos de profunda espiritualidade. Esses serviços novos, embora não sejam continuação direta daqueles que existiram na Igreja em tempos mais antigos, como os sacristães, zeladores e tantos outros, também não deixam de guardar uma certa continuidade com eles.

Constatamos assim que, para além dos ministérios oficialmente confirmados pela Igreja, o Espírito Santo de Deus continua suscitando serviços e carismas para o bem das inúmeras comunidades eclesiais. São exemplos destas novas funções levadas a efeito por dedicados leigos a coordenação das novenas de Natal, Pentecostes, Padroeiros, círculos bíblicos em estilo bem orante, as celebrações exequiais, a distribuição da comunhão para doentes, idosos e sob a forma de viático, as celebrações nas peregrinações, celebrações penitenciais em santuários, a presidência da Liturgia das Horas nas paróquias, comunidades e CEBs, diversos tipos de bênçãos, celebrações na quarta-feira de Cinzas, no domingo de Ramos e no Tríduo Pascal, a Via Sacra etc.

Vê-se que a maior parte de tais celebrações são realizadas por mulheres, e isso pode ser lido como um sinal profético de que é sempre o Espírito do Senhor quem valoriza e continuamente conduz e renova a Igreja de Deus em direção a formas expressivas e eloqüentes de ministérios. Tais ministérios, embora chamados de "supletivos", porque feitos na ausência dos ministros ordenados e, por isso mesmo, tidos por "temporários", na ver- 
dade não o são, porque diferem, enriquecem e complementam a função própria do sacerdote na Igreja.

Os documentos analisados nos oferecem uma visão ampla e diversificada dos ministérios tal como os compreende a Igreja a partir do Concílio Vaticano II. Mas a prática eclesial das últimas décadas também nos sugere um grande número de outros ministérios e serviços, espontaneamente brotados no seio da comunidade, e que igualmente contribuem para delinear cada vez mais o rosto da Igreja como Igreja toda ministerial. Tudo isso enriquece, anima e confirma a mesma Igreja, convocando-a a deixarse guiar sempre pelo Espírito.

Que a reflexão aqui realizada concorra não só para uma visão aprofundada sobre os ministérios litúrgicos hoje, como também nos abra, na força do Espírito Santo, para acolhermos com interesse, disponibilidade e alegria os diversos ministérios que a voz do mesmo Espírito não deixa de sugerir à sua Santa Igreja.

José Raimundo de Melo, SJ, é mestre (1987) e doutor (1993) em Sagrada Liturgia pelo Pontifício Ateneu Santo Anselmo (Roma). É professor de Liturgia na Pontifícia Faculdade de Teologia N. S. da Assunção (São Paulo) e no Pontifício Instituto Oriental (Roma). É autor de vários artigos, publicados em revistas e em obras coletivas.

Endereço: Rua Haddock Lobo, 400 01414-902 São Paulo - SP

e-mail: jraimelo@yahoo.com.br 


\section{Coleção Bíblica Loyola}

A Coleção Bíblica Loyola, sob responsabilidade da Faculdade Jesuíta de Filosofia e Teologia de Belo Horizonte, publica estudos, comentários e subsídios bíblicos de nível científico internacional, seja traduzidos, seja produzidos por biblistas nacionais.

\section{Títulos mais recentes:}

15. Leitura do Evangelho segundo João III (X. Léon-Dufour)

16. Leitura do Evangelho segundo João IV (X. Léon-Dufour)

17. Jesus e o mundo do judaísmo (G. Vermes)

18. A Galiléia, Jesus e os Evangelhos (S. Freyne)

19. As duas fases da pregação de Paulo (M. Pesce)

20. O Evangelho de Mateus e o judaísmo formativo (J. A. Overman)

21. A Bíblia na Igreja (J. A. Fitzmyer)

22. O pensamento do templo - de Jerusalém a Qumran (F. Schmidt)

23. As formas literárias do Novo Testamento (K. Berger)

24. Procurais o Jesus histórico? (R. Zuurmond)

25. Sabedoria e sábios em Israel (J. Vílchez Líndez)

26. Mulher e homem em Paulo (N. Baumert)

27. A evolução do pensamento paulino (U. Schnelle)

28. Metodologia do Antigo Testamento (H. Simian-Yofre [org.])

29. A mensagem do Reino (R. A. Horsley e N. A. Silberman)

30. Abraão e sua lenda: Gênesis 12,1-25,11 (W. Vogels)

31. Israel e seu Deus: (F. Gradl e F. J. Stendebach)

32. Sacrifício e culto no Israel do Antigo Testamento (Ina Willi-Plein)

33. O Jesus Histórico: um manual (Gerd Theissen / Annete Merz)

34. A Tríade: fé, esperança e amor em Paulo (Thomas Söding)

35. A Primeira história do Cristianismo (Daniel Marguerat)

36. Introdução ao Antigo Testamento (Erich Zenger et al.)

37. Introdução à leitura do Pentateuco (Jean-Louis Ska)

38. A "fórmula da aliança" (Rolf Rendtorff)

39. As parábolas de Jesus em Marcos e Mateus (Michel Gourgues)

40. A invenção de Cristo (Maurice Sachot)

41. As origens da Bíblia (John W. Miller)

42. Naquele tempo... Concepções e práticas do tempo (M. Gourgues e M. Talbot)

43. Introdução à exegese do Novo Testamento (U. Schnelle)

44. A encarnação do Filho de Deus (Ulrich B. Müller)

45. Sinopse dos Evangelhos de Mateus, Marcos e Lucas e da "Fonte Q" (J. Konings) 46. Entre os dois Testamentos. História e religião na época do Segundo Templo (J. Maier) 47. As parábolas de Lucas (Michel Gourgues)

48. Religião de visionários: apocalíptica e misticismo no cristianismo primitivo (P.A. de S. Nogueira)

49. O homem bíblico. Leituras do Primeiro Testamento (A. Wénin)

Edições Loyola - Cx. P. 42.355 - CEP 04299-970 São Paulo e-mail: vendas@loyola.com.br 